This item was submitted to Loughborough's Research Repository by the author.

Items in Figshare are protected by copyright, with all rights reserved, unless otherwise indicated.

\title{
The dreamworld of new Yugoslav culture and the logic of cold war binaries
}

PLEASE CITE THE PUBLISHED VERSION

PUBLISHER

(c) Amsterdam University Press

VERSION

AM (Accepted Manuscript)

LICENCE

CC BY-NC-ND 4.0

REPOSITORY RECORD

Mihelj, Sabina. 2019. "The Dreamworld of New Yugoslav Culture and the Logic of Cold War Binaries". figshare. https://hdl.handle.net/2134/13205. 
This item was submitted to Loughborough's Institutional Repository (https://dspace.lboro.ac.uk/) by the author and is made available under the following Creative Commons Licence conditions.

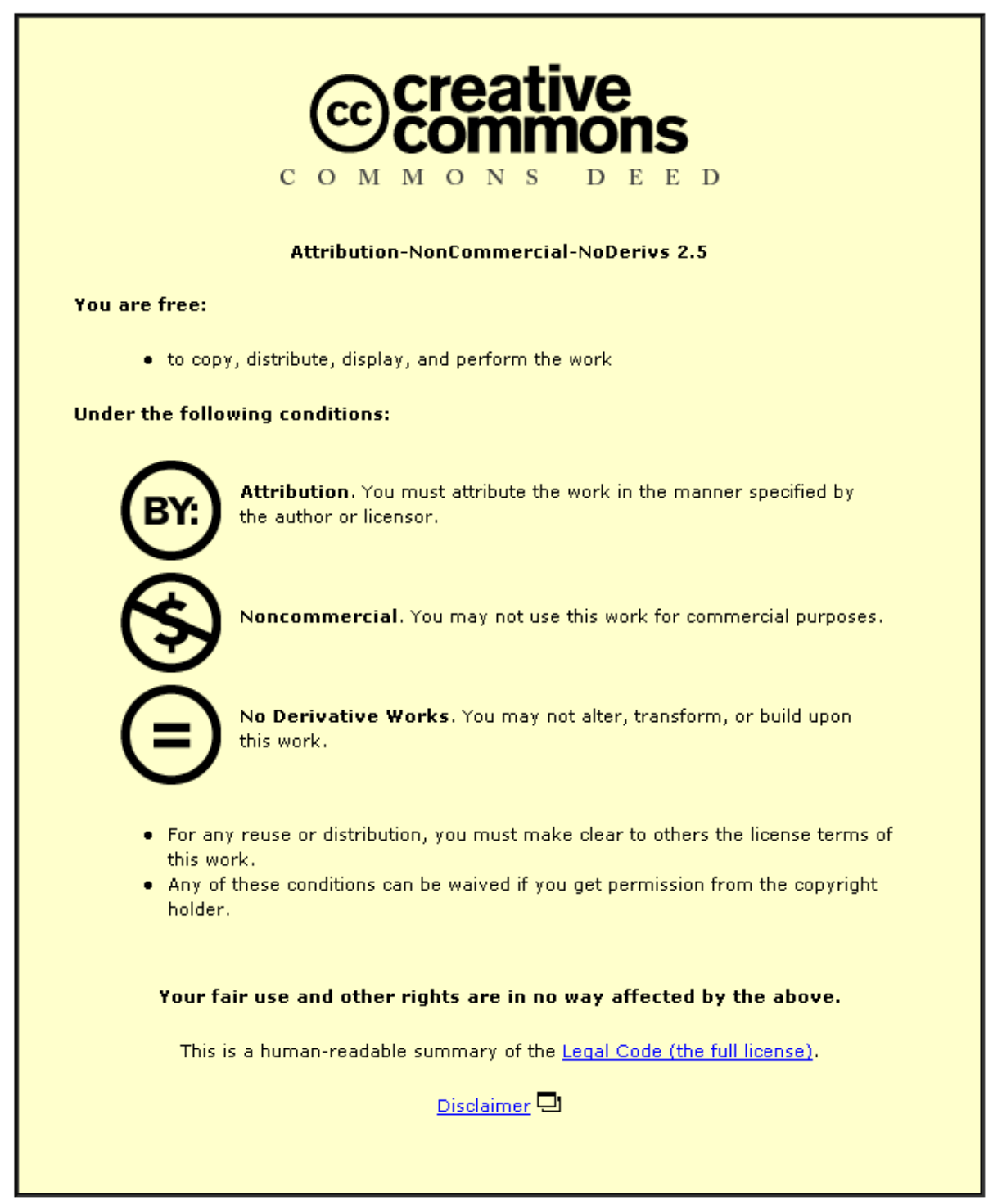

For the full text of this licence, please go to: http://creativecommons.org/licenses/by-nc-nd/2.5/ 
This is a pre-print version. Final version published in: Peter Romijn, Giles ScottSmith and Joes Segal 2012 (eds.) Divided Dreamworlds: The Cultural Cold War in East and West, Amsterdam: Amsterdam University Press.

\title{
The Dreamworld of New Yugoslav Culture and the Logic of Cold War Binaries
}

\author{
Sabina Mihelj
}

'We are following our own path into socialism, and we will not allow anyone, neither those in the East nor those in the West, to make us stray away from this path'. ${ }^{1}$ This statement, taken from a speech delivered by the Yugoslav president Josip Broz Tito at the plenary session of the League of Communists of Yugoslavia (LCY) in 1954, encapsulates what was then the guiding ideological principle of the Yugoslav federation. It also serves as an apposite starting point for discussing the theoretical and methodological limitations of thinking about the Cold War in terms of a rigid East-West divide. A narrative structured around a black-and-white conflict between two ideologically opposed blocks is obviously ill-suited to account for the history of post-World War II Yugoslavia. In the years that followed the Tito-Stalin split in 1948, the Yugoslav political leadership embraced a new set of political and economic principles, centered on the ideal of 'worker's self-management' and premised on a rejection of 'Soviet' or 'Stalinist' models and a rereading of the classics of MarxismLeninism. ${ }^{2}$ In line with this ideological reorientation, the Party was expected to abandon its role as the 'commander' and 'direct operative manager' of social, state and economic life, and instead dedicate itself to the 'political and ideological work in educating the masses'. ${ }^{3}$ Ensuing changes in the Yugoslav foreign policy, characterized by the country's prominent involvement in the Non-Aligned Movement, followed a similar logic, and can be seen as a balancing act aimed at eschewing the logic of bloc politics. ${ }^{4}$

Shifts in the realm of cultural policies were based on the same template. ${ }^{5}$ Already in 1949, Yugoslav communist authorities came to the conclusion that the old approach, aimed at changing popular consciousness and instituting new cultural values with the help of 'administrative means', was misguided, and had to be replaced with a less intrusive and prescriptive approach to culture, more amenable to ideological pluralism. ${ }^{6}$ The Departments of Agitprop and Propaganda were formally abolished in 1952, socialist realism was no longer treated as the only ideologically acceptable paradigm, and Yugoslavia's museums, cinemas, concert halls and bookshops opened their doors to cultural imports from the West. By the mid-1950s, the number of films imported from the United States was over five times higher than in 1949, while the

\footnotetext{
${ }^{1}$ Quoted in Primorske novice, 03/04/1954, 1.

${ }^{2}$ Dennison Rusinow, The Yugoslav Experiment, 1948-1974 (London: C. Hurst \& Company, 1977), p. 61.

${ }^{3}$ Quoted in ibid., p. 75.

${ }^{4}$ Cf. Alvin Z. Rubinstein, Yugoslavia and the Nonaligned World (Princeton: Princeton University Press, 1970).

${ }^{5}$ Studies that trace various aspects of this transformation include Petar Luković, Bolja prošlost. Prizori iz muzičkog života Jugoslavije 1940-1989 (Beograd: Mladost, 1989); Aleš Gabrič, Socialistična kulturna revolucija: Slovenska kulturne politika, 1953-1962 (Ljubljana: Cankarjeva založba, 1995); Predrag J. Marković, Beograd između istoka i zapada 1948-1965. godine (Beograd: Službeni list SRJ, 1996); Andrew Baruch Wachtel, Making a Nation, Breaking a Nation: Literature and Cultural Politics in Yugoslavia (Stanford: Stanford University Press, 1998); and Reana Senjković, Izgubljeno u prijenosu: Pop iskustvo soc culture (Zagreb: Biblioteka nova etnografija, 2008).

${ }^{6}$ Marković, op. cit., pp. 325-7.
} 
This is a pre-print version. Final version published in: Peter Romijn, Giles ScottSmith and Joes Segal 2012 (eds.) Divided Dreamworlds: The Cultural Cold War in East and West, Amsterdam: Amsterdam University Press.

number of Soviet films decreased rapidly. ${ }^{7}$ In 1952, the daily newspaper Politika started publishing Donald Duck comics, and re-launched its popular weekly comic magazine Politikin Zabavnik. ${ }^{8}$ At the same time, the official attitudes towards jazz and popular music in general softened as well, though a measure of suspicion remained. ${ }^{9}$ These changes were accompanied by a new understanding of Yugoslav identity and culture, based on the idea of Yugoslavia as a meeting point of two cultural worlds, which presumably gave rise to a unique cultural hybrid containing elements drawn from both the East and the West.

It is tempting to adopt the categories and phrases used by Yugoslav leaders and policy makers themselves and describe the post-1948 Yugoslav economy, politics and culture in ways they themselves often did, namely as a distinctive blend of West and East, market principles and state control, entertainment and education. Yet is such an approach really capable of overcoming the limitations of Cold War binaries? Not quite. Narrating the history of Tito's Yugoslavia in terms of a separate path into socialism would mean missing the active role of official discourse in molding and appropriating Yugoslav realities, and obscuring those of their features that may not quite fit the self-congratulatory image of Yugoslav uniqueness. While the LCY did indeed give up its monopoly over the political decision-making process, it never abandoned its monopoly over political organization, and retained control over the appointment of key personnel in the country's leading mass organization, the trade unions, municipal governments and elsewhere. ${ }^{10}$ In the realm of economic policy, the state retained a powerful role, and although the successive waves of economic reforms did bring significant changes that helped increase the general well-being of Yugoslav citizens, the Yugoslav system effectively remained socialist in nature, and self-management was never fully implemented in practice. ${ }^{11}$ Changes in the realm of culture were possibly more far-reaching, yet it is important to keep in mind that cultural experimentation was punctuated by periodic purges of cultural institutions, closing down of journals and persecutions. ${ }^{12}$ Neither it is possible to sustain the argument that the Yugoslav experiment was entirely unique in the socialist East. Changes similar to those recorded in Yugoslavia were taking place elsewhere in Eastern Europe and in the Soviet Union itself, especially in the new cultural climate of the Thaw, ${ }^{13}$ making differences between Yugoslavia and the rest of the communist world more a matter of degree than of any profound, qualitative differences. Or, to put it differently: the dreamworld of socialist Yugoslavia after 1948 may well have been premised on the notion of Yugoslav uniqueness, but whether the reality of socialist Yugoslavia was indeed so unique is disputable.

How, then, should we approach the East-West binary and the associated categories and distinctions underpinning the divided dreamworlds of Cold War culture, including those that were - as the Yugoslav one after 1948 - aimed at escaping the

\footnotetext{
${ }^{7}$ Ibid., p. 449.

${ }^{8}$ Ibid., pp. 447-9.

${ }^{9}$ Luković, op.cit., pp. 10-20.

${ }^{10}$ Rusinow, op.cit., pp. 73-4.

${ }^{11}$ Milica Uvalić, Investment and Property Rights in Yugoslavia: The Long Transition to a Market Economy (Cambridge: Cambridge University Press, 1992).

${ }^{12}$ Gabrič, op.cit.; Marković, op. cit., 323-55.

${ }^{13}$ E.g. Susan Reid and David Crowley, eds., Style and Socialism: Modernity and Material Culture in Post-war Eastern Europe (Oxford: Berg, 2000).
} 
This is a pre-print version. Final version published in: Peter Romijn, Giles ScottSmith and Joes Segal 2012 (eds.) Divided Dreamworlds: The Cultural Cold War in East and West, Amsterdam: Amsterdam University Press.

logic of block politics? One fruitful way of inquiry is to delve into the negotiations and adaptations of these dreamworlds in the realm of everyday life, and explore those aspects of cultural practices and forms that eschew the neat distinctions of official discourse and policies. Yet if pursued on its own, this route of exploration risks getting caught in the popular narratives of repression and resistance, which are evidently in tune with contemporary sensibilities and recollections of the socialist past, but fail to capture the logic of Cold War dreamscapes and their role in really existing socialism. To avoid this, we need to complement this approach with another line of inquiry - one pursued also in this chapter - which involves treating Cold War categories and distinctions as objects of analysis in their own right, examining their discursive logic and uses in particular social contexts, and their relationship with the fluid nature of cultural processes, events and products they are meant to describe. This method of inquiry enables us to move beyond the simple acknowledgement of the mismatch between official proclamations and everyday practices, and gain a closer insight into the nature of this mismatch, its epistemic effects and links with relationships of power and social divisions. Gaining such insight is of vital importance if we are to fully appreciate the role of binary thinking during the Cold War and overcome its legacies in contemporary debates about the period.

\section{Yugoslav culture and early Cold War binaries in the Yugoslav northeast}

The rest of this chapter applies this analytical approach to a case study, namely the journalistic discourse about culture in the north-western part of Yugoslavia, encompassing the region bordering Italy and the eastern side of the upper Adriatic coast. The proximity of Italy, the bilingualism of the local population, and the presence of ethnic minorities on both sides - Italians in Yugoslavia and Slovenians in Italy - were a constant source of inter-ethnic tensions, suspicions and even violence, ${ }^{14}$ but also encouraged cross-border exchanges even at the height of Cold War tensions, and obstructed the processes of cultural homogenization and nation-building on each side of the border. Italian radio and later television channels were immensely popular with the local Yugoslav audiences, and from the mid-1950s onwards, when special passports were introduced for local residents, shopping trips and visits to friends and family members in Italy became increasingly common. ${ }^{15}$ At the same time, many Italians and Slovenian minority members living in Italy became regular customers of local Slovenian and Croatian restaurants and petrol stations, followed radio and television programs broadcast from Yugoslavia, and also formed a substantial proportion of foreign tourists visiting the Yugoslav coastal resorts.

To examine the key traits of the early Cold War discourse about culture in the shifting ideological and cultural landscape of the region, this chapter focuses on the immediate post-World War II period up to 1948, when Yugoslav cultural forms and practices were organized, both institutionally and discursively, in much the same way as their equivalents in the Soviet Union and elsewhere in communist Eastern Europe. The media covered in the analysis include all the major Croatian and Slovenian newspapers published in the north-western part of the federation (Riječki list/ Novi list, Glas Istre, Primorske novice), the pro-Yugoslav Slovenian minority newspaper

\footnotetext{
${ }^{14}$ Marina Cattaruzza, L'Italia e il confline orientale (Bologna: Il Mulino, 2007), pp.168-81.

${ }^{15}$ Jože Šušmelj, 'Videmski sporazum', in Jože Pirjevec, Gorazd Bajc and Borut Klabjan, eds., Vojna in mir na Primorskem (Koper: Založba Annales, 2005) pp. 307-322.
} 
This is a pre-print version. Final version published in: Peter Romijn, Giles ScottSmith and Joes Segal 2012 (eds.) Divided Dreamworlds: The Cultural Cold War in East and West, Amsterdam: Amsterdam University Press.

issued in Trieste (Primorski Dnevnik), and one Italian minority newspaper (La Voce del Popolo). It is important to clarify the limitations imposed by the nature of primary sources used. Especially in the early post-war years, the press largely reflected official views and did not exert an independent influence on cultural processes. ${ }^{16}$ This was also a period when literacy rates were relatively low and local resistance to communist policies fairly widespread. Therefore, it may well be that the framing of culture promoted by the press was largely ignored by the wider population. Accepting this proposition, however, would mean confusing influence with approval; while the socialist Yugoslav press certainly cannot be taken as an accurate expression of public culture as a whole, it nevertheless played a major role in delineating the boundaries of what was publicly acceptable, and imposing 'a structure of thinking' even among those who did not support the regime. ${ }^{17}$ It is also worth keeping in mind that the Cold War, similarly as all other twentieth century wars, was a truly mass phenomenon.

Fought in an era when power was exercised in the name of the masses, wars required extensive mobilization of civilians into army troops and depended on mass support or at least an illusion of mass support - among citizens-voters who formed part of the 'home front' and participated in the battle as distant spectators. As such, total wars could not exist without the mass media, which forged symbolic bonds between the soldiers at the front and the population at home, providing both with images of triumphant self-assertion and of the threatening, devious acts of the enemy. ${ }^{18}$ The cultural contest that formed part of the Cold War was no different in this respect, which makes the examination of journalistic framings of culture vitally important to its understanding.

Throughout the period examined in this chapter, the border between Italy and Yugoslavia remained in flux. As the Cold War rivalry began to take shape, the territorial dispute between the two neighboring states assumed a strategically important geopolitical role. Consequently, the fate of the port city of Trieste and the surrounding area became a burning issue not only for Italy and Yugoslavia, but also for 'The Big Four' - the Soviet Union, the United States, the United Kingdom and France - who took over the task of finding a solution to the 'Trieste problem'. ${ }^{19}$ Following the signing of the Paris Peace Treaty in 1947, an interim solution was implemented, which included the establishment of the Free Territory of Trieste, an unusual political formation comprising Trieste and its immediate surroundings. The territory was divided into two zones, one controlled by the Allied Military Government and the other by the Yugoslav army. The legitimacy of this solution remained disputed, and much of the local population, in particular in Trieste, continued to live in a state of perpetual mass mobilization. ${ }^{20}$ The inclusion of much of the Istrian peninsula into communist Yugoslavia also prompted yet another wave of mass migration; in total, almost half of the Italian population living in these

16 Gertrude Joch Robinson, Tito's Maverick Media: the Politics of Mass Communications in Yugoslavia (Urbana, Chicago and London: University of Illinois Press, 1977), pp. 16-25; Carol S. Lilly, Power and Persuasion: Ideology and Rhetoric in Communist Yugoslavia, 1944-1953 (Boulder, CO: Westview Press, 2001), pp. 43-45.

${ }^{17}$ Cf. Jeffrey Brooks, Thank You, Comrade Stalin! Soviet Public Culture from Revolution to Cold War (Princeton: Princeton university Press, 2000), p. xiv.

${ }^{18}$ Susan L. Carruthers, The Media at War (Basingstoke: Palgrave Macmillan, 2000), pp. 54-107.

${ }^{19}$ Glenda Sluga, The Problem of Trieste and the Italo-Yugoslav Border: Difference, Identity, and Sovereignty in Twentieth-Century Europe (Albany: State University of New York Press), pp. 133-155.

${ }^{20}$ Bogdan C. Novak, Trieste, 1941-1954: The Ethnic, Political and Ideological Struggle (Chicago: University of Chicago Press, 1970). 
This is a pre-print version. Final version published in: Peter Romijn, Giles ScottSmith and Joes Segal 2012 (eds.) Divided Dreamworlds: The Cultural Cold War in East and West, Amsterdam: Amsterdam University Press.

territories, along with a number of anti-communist Slovenians and Croatians, left for Italy and other countries, and were replaced by immigrants from other parts of Yugoslavia. $^{21}$

Operating in this volatile context, marked by the intensification of the global confrontation between the United States and the Soviet Union., the press was involved in a constant ideological battle. Along with the rest of the Yugoslav media, it formed part and parcel of a complex apparatus for cultural change, modeled on the one established in the Soviet Union and aimed at fostering the rise of a new, socialist Yugoslav culture. ${ }^{22}$ Although the Yugoslav press was legally free and not owned directly by the state or the Communist Party of Yugoslavia (CPY), this apparatus nevertheless provided ample opportunities for the CPY to filter undesirable content and use the press as a collective agitator and propagandist. The Departments of Agitprop and Propaganda were regularly sending out detailed instructions on the most desirable cultural content, supplying the newspapers with ready-made articles, monitoring the content of newspapers for ideological purity, and giving recommendations about editorial board membership. ${ }^{23}$ The CPY also used its influence over the legislative, judicial and executive bodies to pass and enforce legislation favorable to the Communist Party. For example, although the 1945 Law on the Press guaranteed free expression of opinion, the Criminal Law at the same time allowed for various more or less direct ways of censorship. ${ }^{24}$ This legislative framework enabled the communist officials to issue publishing permits only to 'loyal' publishers, boost the circulation of party-sponsored newspapers by allocating press subsidies, and prevent the spreading of un-orthodox views by limiting the use of paper, denying access to printing facilities, delaying various bureaucratic procedures, and even confiscating the printing presses. ${ }^{25}$ Finally, most major newspapers were founded by the Peoples' Front of Yugoslavia, a mass organizations that shared CPY's ideological convictions.

Ideologically, the normative views about Yugoslav culture promoted by the CPY in this period were rooted in Marxist-Leninist perceptions of modernity and society, centered on the notion of culture as a tool of progress and elevation of the working classes. Three closely intertwined features of these normative framing were particularly prominent in the analyzed newspaper coverage: (a) the understanding of culture as a tool of progress and education; (b) the emphasis on a distinctly socialist nature of progress that culture was expected to foster, (c) the conviction that ideological content of culture was more important than its aesthetic form, and (d) the privileging of mass over elite culture. On every account, the 'new Yugoslav culture' was construed as the exact opposite of 'bourgeois' culture of the pre-war past, which also allegedly continued to flourish in the capitalist West. The cosmology drawn by

\footnotetext{
${ }^{21}$ The latest estimates put the total number of those who left between 1941 and 1961 at 302.000, and those who immigrated at 198.000. Olinto Mileta Mattiuz, 'Gli spostamenti di popolazione nel territorio annesso alla Jugoslavia dopo la Seconda guerra mondiale. Tentativo di quantificazione demografica', in Dopoguerra di Confine - Povojni čas ob meji, eds. Tullia Catalan, Giulio Mellinato, Raoul Pupo, Marta Verginella (Trieste: Regione Autonoma Friuli-Venezia Giulia, Università di Trieste and Istituto regionale SML nel Friuli-Venezia Giulia, 2007), pp. 687-704.

${ }^{22}$ Lilly, op.cit., pp. 35-54.

${ }^{23}$ Ibid., pp. 39-41.

${ }^{24}$ Božidar Novak, Hrvatsko novinarstvo u 20. stoljeću (Zagreb: Golden Marketing - Tehnička knjiga, 2005), p. 460

${ }^{25}$ Robinson, op.cit., pp. 16-25; Lilly, op.cit., pp. 43-45.
} 
This is a pre-print version. Final version published in: Peter Romijn, Giles ScottSmith and Joes Segal 2012 (eds.) Divided Dreamworlds: The Cultural Cold War in East and West, Amsterdam: Amsterdam University Press.

the media was one of clear divisions and black-and-white contrasts, which neither acknowledged nor tolerated any shades of grey.

Culture as a tool of progress. To start with, the new Yugoslav culture was seen as an integral instrument of progress, and was expected to foster the cultural, ideological and civilisational 'elevation' of the Yugoslav population by cultivating its cultural awareness and sensibility, inculcating the ability to appreciate and understand art, as well as stimulating the acquisition of technical and physical skills - in other words, to encourage Bildung in the original German sense of the word. For instance, in one article, government investment into the renovation of a 'home of the people' [narodni in one of the Istrian villages - a building that would typically serve as a venue for local gatherings, literacy classes and various other activities - was presented as evidence of government support for 'raising the cultural level' of the population. ${ }^{26}$ In a similar vein, a report summarizing the plan of work of the theatre in Rijeka was inviting workers to 'treat theatre as their home', arguing that this would 'help in their general and cultural elevation and raise the level of artistic education' ${ }^{27}$ As with other elements of the journalistic framing of Yugoslav culture in this period, the belief in culture-induced 'elevation' was shared by the Soviet system of cultural values, as established in the post-revolutionary period. ${ }^{28}$

As the above-quoted examples suggest, the provision of cultural activities and infrastructure that would foster the elevation of the whole population was seen as a key task of local cultural institutions as well as government authorities. In this sense, the notion of culture as an instrument of progress was used for the purpose of institutional self-legitimation, including the self-legitimation of the ruling communist authorities themselves. Yet the duty to foster the development of new Yugoslav culture was not in the exclusive domain of the state and the party. Quite to the contrary, organizations and individuals at virtually all levels of society were expected to contribute to this endeavor. These expectations were clearly visible in the coverage of mobilizational activities designed to boost Yugoslav productivity, including short periods of intensive industrial production known as 'shockwork' and various competitions between local factories, schools, and other organizations. These activities were based on the Russian Stakhanovite movement and had their precedents in 1930s Soviet Union. ${ }^{29}$ Announcements and journalistic reports of these mobilizational events were a common sight in the local media, and often received a prominent position on the first few pages of the newspapers. As one article explained, cultural activities formed an integral part of the process of 'ideological elevation', which was designed to accelerate the industrialization of the country and help construct the 'new Yugoslavia'. Given the importance of culture to Yugoslav development, the author was concerned about the lack of cultural events accompanying mobilizational activities, and appealed to the local labor union organizations to invest more effort in promoting education and literacy among the population. This example shows how the notion of culture as an instrument of progress served not only as a discursive tool of power legitimation, but also as an

\footnotetext{
${ }^{26}$ Photo-news article without title, Glas Istre, 03 October 1947, p. 10.

${ }^{27}$ J.K., 'Plan rada narodnog kazališta u novoj sezoni', Riječki list, 05 September 1947, p. 3.

${ }^{28}$ Shiela Fitzpatrick, The Cultural Front: Power and Culture in Revolutionary Russia (Ithaca: Cornell University Press, 1992), pp. 217-219, Hoffmann, Stalinist Values: The Cultural Norms of Soviet Modernity, 1917-41 (Ithaca: Cornell University Press, 2003), pp. 15-56.

${ }^{29}$ Lilly, op.cit., pp.118-20.
} 
This is a pre-print version. Final version published in: Peter Romijn, Giles ScottSmith and Joes Segal 2012 (eds.) Divided Dreamworlds: The Cultural Cold War in East and West, Amsterdam: Amsterdam University Press.

instrument of normative assessment, used to distinguish between the good, commendable aspects of cultural processes and events, and the less worthy ones.

Closely linked to these normative ideas was the treatment of cultural skills and artifacts as an indicator of the country's level of civilization and progress. Attitudes to literacy are a case in point. High levels of illiteracy, common especially among the rural population, were seen as major markers of cultural and civilisational underdevelopment, 'suffocating the free labor force and enthusiasm for work among our people' and thereby hindering the progress of villages as well as the realization of the five year plan. ${ }^{30}$ Several articles were urging the local population and in particular the Yugoslav youth and women to attend literacy classes. As one article insisted, illiteracy should be erased from Tito's Yugoslavia, 'since it is only in this way that we will be able to build the country and make it cultured and progressive' ${ }^{31}$ Or, as one Yugoslav citizen explained in a letter he wrote as part of his literacy training: 'The war is over, but we need to continue with our struggle against illiteracy'. ${ }^{32}$ Literacy, in other words, was believed to constitute a core element of Yugoslavia's development, and diminishing illiteracy rates served as material proof of the country's progress.

Apart from providing the normative basis for assessing the level and quality of Yugoslav culture from within, the understanding of culture as a means of progress also functioned as a marker of Yugoslav identity in relation to its various external others, be they historical or contemporary. In this sense, the notion of culture as a tool of development was used to position the new Yugoslav culture geo-culturally, in relation to the East and the West, as well as historically, in relation to the 'old' culture of the pre-war decades. Articles promoting 'cultural elevation' routinely referred to the neighboring country and the Fascist rule in particular as the party responsible for the cultural 'backwardness' of the local population. An article reporting on a cultural youth festival in Buje thus contrasted the flourishing cultural life of the village in the new Yugoslavia with the cultural wasteland of pre-war decades, when the local population 'was left without its own language, without books and education and without opportunities for cultural development'. ${ }^{33}$ The same message was repeated in a report summarizing the achievements of the new administration in one of the localities in Istria, where Fascism was blamed for the obstacles faced by the new administration, in particular for the low literacy rates and education among locals. ${ }^{34}$

Such sharp contrasts between the past and the present, 'us' and 'them', obscured fundamental continuities with the pre-war past, as well as similarities with cultural policies and practices on the other side of the Iron Curtain. The idea of culture as a tool and marker of development was widely spread across nineteenth-century Europe and constituted one of the guiding principles of the rise of mass literacy and the numerous campaigns for compulsory education, all of which were, much as the campaigns for literacy documented in Yugoslav newspapers, couched in the language

\footnotetext{
30 'Narodna vlast vodi brigu o podizanju kulturnog nivoa naroda', Glas Istre, 03 October 1947, p. 10.

${ }^{31}$ Marija Banko, "Najveća nam je briga naučiti čitati i pisati”, Glas Istre, 07 March 1947, p. 5.

${ }^{32}$ The letter was reproduced in Glas Istre, 07 March 1947, p. 5.

${ }^{33}$ T.D., 'Omladinska smotra kulture u Bujama', Glas Istre, 07 March 1947, p. 5.

${ }^{34}$ Julij Beltram, 'Dosedanji rezultati dela ljudske oblasti v Koprščini in Bujščini', Primorski dnevnik, 03 Sept 1947, p. 1.
} 
This is a pre-print version. Final version published in: Peter Romijn, Giles ScottSmith and Joes Segal 2012 (eds.) Divided Dreamworlds: The Cultural Cold War in East and West, Amsterdam: Amsterdam University Press.

of progress. ${ }^{35}$ The practice of viewing the acquisition of cultural skills as an index of progress has its roots in the same period, and coincided with the rise of modern states and mass democracy that demanded authorities to legitimize their power by, among other things, providing the population with means of cultural progress. ${ }^{36}$ In the postwar years, the efforts to enlist culture in the struggle against backwardness were common across the east East-West divide, and also underpinned much of the US research on modernization and development in the Middle East and Latin America. ${ }^{37}$ The close link between culture and progress was thus something that was neither particularly new nor unique to the socialist East, but instead constitutes on of the key features that attest the shared roots of the understanding of culture on both sides of the Cold War divide.

Culture as an instrument of socialist modernization. While helping raise the general civilisational level of the local population, cultural activities in the new Yugoslavia were also meant to fulfill more specifically socialist goals. To this end, Yugoslavia needed a culture that was not aimed solely at entertainment, but was dedicated primarily to the cultivation of specifically socialist values and sensibilities. An unsigned article published in the Italian minority daily thus criticized the local labor unions for putting too much emphasis on entertainment and staging too many 'light' plays and comedies, and for stuffing local libraries with sentimental novels instead of providing cultural activities capable of promoting socialist principles and helping recruit volunteers for shockwork and the youth labor brigades. ${ }^{38}$ Such popular entertainment, it was argued, will instill idleness and promote worldly pleasures instead of mobilizing the population for the construction of socialism. Modern dance and music, including boogie-woogie, jazz and swing, popularized by Allied soldiers in neighboring Italy ${ }^{39}$ and trickling through the Free Territory of Trieste and across the border into Yugoslavia, were particularly often coming under attack. In one article, jazz was described as 'hysterical', 40 while another suggested that 'boogiewoogie 'has nothing to do with culture'. ${ }^{41}$ These anxieties were shared by Soviet Party officials, who were constantly concerned about the vulnerability of the Russian people to various cultural seductions and deviations orchestrated by the capitalist world. ${ }^{42}$ To be sure, both leisure and entertainment were considered legitimate and necessary, yet the key task of Yugoslav cultural manifestations lay elsewhere: 'they should inculcate seriousness of life needed for the construction of the new state, they should teach people to take pride in work, to take pride in making a contribution to the creation of a common future'. ${ }^{43}$ Another article was similarly prescriptive, and

\footnotetext{
${ }^{35}$ David Vincent, The Rise of Mass Literacy: Reading and Writing in Modern Europe (Cambridge: Polity Press, 2000), pp. 7-10.

${ }^{36}$ Ibid., pp. $21 \mathrm{ff}$.

${ }^{37}$ E.g. Karl W. Deutsch, 'Social mobilization and political development', The American Political Science Review, Vol. 55, No. 3, pp. $493-514$ (1961); Daniel Lerner, The Passing of Traditional Society: Modernizing the Middle East (New York: Free Press, 1958).

${ }^{38}$ N., 'Più contenuto nei programmi artistici', La Voce del Popolo, 03 Jan 1947, p. 3.

${ }^{39}$ Cf. Stephen Gundle, Between Hollywood and Moscow: The Italian Communists and the Challenge of Mass Culture, 1943-1991 (Durham and London: Duke University Press, 2000), pp. 32-5.

${ }^{40}$ Sequi, 'Per la nuova cultura', p. 1.

41 'Gledaliških dvoran za SNG ni, fašistom pa so vedno na razpolago' Primorski dnevnik, 03 Dec 1947, p. 2 .

42 David Caute, The Dancer Defects: The Struggle for Cultural Supremacy during the Cold War (Oxford and New York: Oxford University Press, 2003), p. 7.

${ }^{43}$ N., 'Più contenuto nei programmi artistici', La Voce del Popolo, 03 Jan 1947, p. 3.
} 
This is a pre-print version. Final version published in: Peter Romijn, Giles ScottSmith and Joes Segal 2012 (eds.) Divided Dreamworlds: The Cultural Cold War in East and West, Amsterdam: Amsterdam University Press.

argued that more should be done to set up cultural events aimed at promoting people's participation in agricultural and other activities laid out in the five year plan.

The emphasis on the educational and mobilizational role of culture also played a key role in the selection of various fictional and semi-fictional cultural forms published in the same newspapers. For instance, the protagonists of short stories, serialized novels and comic dialogues were most often model socialist workers or peasants, involved in a revolutionary battle or in heroic re-building of their war-torn society. One such serialized novel was set in the context of the October Revolution, ${ }^{45}$ while another featured Istria peasants reminiscing about their resistance activities during World War II, and proudly talking about the freedom brought to them by the new Yugoslav rule. ${ }^{46}$ As a rule, Western politicians featuring in such novels or short stories were portrayed in a negative light: in one case, former US president Herbert Hoover was described as a 'warmonger', while another involved a mocking portrayal of Harry Truman. ${ }^{47}$ The comic dialogues between Franina and Jurina, appearing on the pages of the Croatian language newspaper Glas Istre, offer another example. The protagonists of these dialogues were always the same: two Istrian peasants talking in the local dialect, one somewhat more ignorant than the other and usually a target for mild ridicule as well as education. In each episode of the dialogue, the better-informed protagonist would talk to his friend about an important event or issue and criticize him for knowing so little about it. In all cases, the events and issues discussed were taken from the Party's agenda for that week or day, and included for instance the five year plan and the Yugoslav state budget, the building of the new railway system, and the 30th anniversary of the October Revolution. ${ }^{48}$

As with the notion of culture as a tool of progress, the emphasis on educationcentered culture as an instrument of socialist Yugoslav modernization can easily lead us to miss important similarities with attitudes and process in the West as well as links with long-term developments on both sides of the Cold War divide. To start with, disdain for popular entertainment was certainly not unique to the socialist East. The popularity of American movies, music, and dances among young East and West Germans in the early 1950s provoked strikingly similar responses in both Germanies, causing anxiety over the oversexualization of women and feminization of men purportedly stimulated by these cultural forms. ${ }^{49}$ Reactions among contemporaries in neighbouring Italy were often rather similar, though negative attitudes to popular entertainment were widespread primarily among supporters of the Communist Party, while Catholic circles quickly became rather adept at appropriating popular cultural forms to their own benefit. ${ }^{50}$ Across Western Europe, and in fact even in the American 'empire of fun' itself, new forms of entertainment were provoking mixed reactions, which often varied with age, gender, race and socioeconomic background,

\footnotetext{
${ }^{44}$ Štefica Kopitar: 'O nekim nedostacima u postavljanju kulturno-prosvetnog rada', Glas Istre, 03 October 1947, p. 10.

${ }^{45}$ Kononov, 'Djevojka sa severa', Glas Istre, 07 November 1947, p. 6.

${ }^{46}$ Zora Pamić, 'Prve brazde', Riječki list, 03 March 1947, p. 3.

${ }^{47}$ Boris Gorbatov: 'Harry Truman' and 'Herbert Hoover vojni hujskač', both in Primorski Dnevnik, 1947.

48 'Franina i Jurina', Glas Istre, 03 April 1947, p. 7, 07 March 1947, p. 7, and 07 November 1947, p. 7, respectively.

${ }^{49}$ Uta G. Poiger, Jazz, Rock, and Rebels: Cold War Politics and American Culture in a Divided Germany (Berkeley, Los Angeles and London: University of California Press, 2000), pp. 31-70.

${ }^{50}$ Gundle, op.cit., pp. 35-54.
} 
This is a pre-print version. Final version published in: Peter Romijn, Giles ScottSmith and Joes Segal 2012 (eds.) Divided Dreamworlds: The Cultural Cold War in East and West, Amsterdam: Amsterdam University Press.

and did not coincide with territorial and cultural boundaries. Neither was this mixture of suspicion and enthusiasm limited to the post-World War II period. ${ }^{51}$ For instance, the notion that cultural activities should be dedicated primarily to educational ends was common among British socialists already in the late nineteenth century. Their struggle for the reduction of working hours went hand-in-hand with growing concern over how workers should best spend their leisure time, and worries over the impact of commercial entertainment. ${ }^{52}$ Evidently, the anxieties surrounding popular culture encountered in socialist Yugoslavia were feeding on a long tradition of cultural fears associated with the rise of mass society, consumerism and modernity, and marked post-Cold War cultural policies and discourses about culture in both in the East and the West.

Substance over form. The binary of entertainment and education was closely intertwined with another key distinction underpinning the journalistic writing about culture in the Yugoslav northwest, namely the distinction between 'substance' and 'form'. As with other aspects of journalistic discourse about culture discussed so far, this feature echoed debates in the Soviet Union in the post-revolutionary period ${ }^{53}$ and had parallels with debates about culture elsewhere in the Eastern block at the time. ${ }^{54}$ Yugoslav art critics were frequently warning against 'purely formal beauty', 'art for art's sake' and 'ideologically empty art', presenting them as remnants of the 'old', 'bourgeois' culture that distracted the masses from real social problems and rational explanations and solutions. Due to this, argued various authors, ideological substance should be treated as decisive when evaluating a work of art. A characteristic example can be found in a commentary published on the cover page of La Voce del Popolo, written by Eros Sequi, the first secretary of the Union of Italians. In his view, people should be prepared to compromise on the 'external aspects' of culture, and keep in mind that 'external beauty can only be established once one has assured a progressive substance'. Only songs, poetry and scenes related to 'actual problems', even if 'deficient in artistic form', argued Sequi, will have the capacity to educate the masses and teach them how to enjoy art for its ideological substance rather than merely artistic form. ${ }^{55}$

The distinction between substance and form was repeatedly drawn upon in articles about various cultural activities in the region, and positive assessments typically referred to correct ideological content. The already mentioned report on the cultural youth festival organized in the Istrian village of Buje commended the participants for staging 'good plays', and as evident from their titles, a prime criterion was the inclusion of socialist ideas or motives from the Yugoslav partisan struggle during World War Two. One such play, entitled The Hotel of the Past, was praised for revealing 'the deception, exploitation and inhospitality in hotels of the past', and implicitly suggesting that the Yugoslav hotels of the future will be fairer to both their

\footnotetext{
${ }^{51}$ Reinhold Wagnleitner, 'The Empire of the Fun, or Talkin' Soviet Union Blues: The Sound of Freedom and U.S. Cultural Hegemony in Europe', Diplomatic History Vol. 23, No. 3, pp. 499-524 (1999).

${ }^{52}$ Chris Waters, British Socialists and the Politics of Popular Culture, 1884-1914 (Stanford, CA: Stanford University Press).

${ }^{53}$ Fitzpatrick, op.cit., pp. 196-198.

${ }^{54}$ Caute, op.cit., pp. 284-285, 380-382, 420-422.

${ }^{55}$ Eros Sequi, 'Per la nuova cultura', La Voce del Popolo, 01 January 1947, p. 1.
} 
This is a pre-print version. Final version published in: Peter Romijn, Giles ScottSmith and Joes Segal 2012 (eds.) Divided Dreamworlds: The Cultural Cold War in East and West, Amsterdam: Amsterdam University Press.

employees and guests. ${ }^{56}$ Following similar criteria, a review of cultural events organized by the local labor unions disappointedly commented on the 'ideological emptiness' of some of the events, and listed several theatre plays that would have allegedly better served the purpose of education and mobilization. ${ }^{57}$

The contrast between ideological emptiness and progressive substance was used also to demarcate the 'new' Yugoslav culture in spatial, geo-cultural terms. The exemplary models of cultural products and activities that paid due attention to 'substance' were often found in the Soviet Union, while negative examples of 'formalistic' culture were associated primarily with 'the West'. In an article about Soviet culture translated from the Soviet daily Pravda, Western culture and civilization were described as 'superficial', hiding a 'spiritual poverty of contemporary imperialists and their followers'. In contrast, Soviet culture allegedly 'arose from and blossoms on the basis of a genuine democracy, brotherly friendship of equal nations', and now 'provides the rallying point for all the progressive forces of the world' ${ }^{58}$ Differences between Yugoslav and Italian culture were scrutinized through the same normative lens. The article written by Eros Sequi is particularly revealing in this respect. In his view, Italians, including those living in Yugoslavia, were prone to a 'misguided', 'bourgeois' and overly 'formalistic' treatment of art and culture, since their cultural capabilities were 'most ruthlessly manipulated and made deviant by decades of Fascism'. ${ }^{59}$ This 'deviant' culture was seen not only as an integral element of 'the old society' dominating in neighboring Italy, but also as 'the secret weapon of imperialism' operating from within the socialist Yugoslav state itself, and hampering its progress. In contrast, local inhabitants of Slavic descent were considered to be 'much more open to re-education', since their cultural sensibilities have allegedly not been contaminated by the educational system of Fascist Italy. ${ }^{60}$

Yet again, we see how the binary of 'form' and 'substance' was used to legitimize some cultural endeavors and discredit others, thereby establishing a hierarchy of cultural products and events within the Yugoslav northwest itself as well as promoting the superiority of Yugoslav culture internationally and historically. As with the binary pairs of categories discussed earlier, these hierarchical distinctions drew a symbolic map of the world that had its own powerful effects, but can hardly serve as an accurate guide to general cultural values and production at the time, let alone their historical roots. During the early Cold War, assaults on formalism had many proponents among the intellectual Left in Western Europe and were not necessarily accompanied by a wholesale rejection of modernism or by commitment to socialist realist art. ${ }^{61}$ The general population in the United States was also not particularly enthusiastic about modernist abstractions and stylistic innovation in poetry and prose, despite the fact that avant-garde art often promoted internationally as a defining feature of 'American' art. ${ }^{62}$

\footnotetext{
${ }^{56}$ T.D., 'Omladinska smotra kulture'.

${ }^{57}$ N., 'Più contenuto'.

58 'Svjetski značaj sovjetske kulture', Riječki list, 05 September 1947, p. 3.

${ }^{59}$ Sequi, 'Per la nuova cultura', p. 1.

${ }^{60} \mathrm{Ibid}$.

${ }^{61}$ Katarzyna Murawska-Muthesius, 'Modernism between peace and Freedom: Picasso and Others at the Congress of Intellectuals in Wrocłav, 1948,' in David Crowley and Jane Pavitt, eds., Cold War Modern: Design 1945-1970 (London: V\&A Publishing), pp. 33-41.

${ }^{62}$ Caute, op.cit., pp. 11-2.
} 
This is a pre-print version. Final version published in: Peter Romijn, Giles ScottSmith and Joes Segal 2012 (eds.) Divided Dreamworlds: The Cultural Cold War in East and West, Amsterdam: Amsterdam University Press.

Culture for the masses. The final notable feature of the journalistic framing of culture $\mathrm{n}$ the Yugoslav northwest in the immediate post-war years was its endorsement of the mass character of culture. The new Yugoslav culture was expected to extend its appeal well beyond the educated elites and thereby contribute to the erasure of class boundaries. Writers, poets and intellectuals were requested to dedicate their work to the working people and serve their interests and needs. Yugoslavia was to be a country in which culture addressed the genuine needs of the working masses, in which the qualitative distinction between elite and mass culture was abolished, and in which high-quality culture was produced and enjoyed at a mass scale. An article written by a prominent Croatian language teacher, journalist and writer proudly announced that Yugoslavia was 'a country of new culture, in which a book is not a good produced for the market, but $[\ldots]$ an integral part of working people's life' ${ }^{63}$ Not all of the cultural products and activities at the time, however, were equally successful at attracting mass participation, and much of the reporting on cultural activities was dedicated to criticizing particular events and activities for failing to live up to the new cultural ideals. For example, an article evaluating the cultural-educational activities in the city of Rijeka and its surroundings criticized the organizers for their failure to establish strong ties with mass organizations and achieve greater popular appeal. ${ }^{64}$ The already discussed article detailing the work plan of the theatre in Rijeka was marked by the same normative assumptions about the role of culture, emphasizing the efforts to 'massify the theatre' and 'turn the whole nation into a theatre audience' by introducing season tickets for labor union members. ${ }^{65}$

As with other aspects of the journalistic understanding of Yugoslav culture, mass appeal served not only to define the 'new' Yugoslav culture from within, but also played a key role in distinguishing it from Italian and more broadly 'Western' culture. While the articles acknowledged that Italian culture is highly developed, they were also pointing out that the ability to appreciate and enjoy it was limited to the wealthy, educated elites rather than being democratically available to its whole population, including the working classes. The aforementioned article discussing the work plan of the local theatre contrasted the strategies for massification adopted by the theatre with the situation under Italian rule, when the authorities 'calculatedly diverted the working people from theatre, deliberately entertaining them with light comedies [...] in order to distract them from political and social problems' ${ }^{66}$ In contrast, the Soviet Union was presented as a shining example of the growing 'massification' of culture, exemplified in the mushrooming of cultural institutions and activities that made culture available to the masses. An article translated from Pravda, which depicted the cultural and educational achievements of the Soviet Union since the revolution, also included details about the number of new theatres and schools built and books issued since the revolution, and boasted about the rising educational level of the general population. ${ }^{67} \mathrm{~A}$ similar quantitative approach to measuring cultural development was employed when assessing the cultural progress of Yugoslavia. Occasionally, newspapers published lists with exact numbers of books issued, new magazines and newspapers established, or libraries built since the formation of the 'new' Yugoslavia.

\footnotetext{
${ }^{63}$ Tone Peruško, 'Nagradjena knjiga o Rijeci', Riječki list, 02 March 1947, p. 3.

${ }^{64}$ Kopitar, 'O nekim nedostacima ...'.

${ }^{65}$ J.K., 'Plan rada narodnog kazališta'.

${ }^{66}$ Ibid.

${ }^{67}$ Kaftanov, '30 godina ...', p. 8.
} 
This is a pre-print version. Final version published in: Peter Romijn, Giles ScottSmith and Joes Segal 2012 (eds.) Divided Dreamworlds: The Cultural Cold War in East and West, Amsterdam: Amsterdam University Press.

These clear-cut distinctions again obscure continuities with the past and neglect structural similarities in cultural practices and values on both sides of the Iron Curtain. Although ideas about the desirable content of culture varied greatly, being able to provide culture for the masses was a goal pursued by intellectuals and politicians on both sides of Cold War divide, at least in the early post-war years. ${ }^{68}$ In the United States, modern means of mass communication in particular were believed to constitute a powerful instrument of cultural development and modernization. For many American social scientists and UNESCO officials at the time, the media were 'great multipliers', capable of increasing the amount of information people can send and receive to unimaginable scales, and thereby speeding up processes of social and economic change in even the most remote backwaters of the world. ${ }^{69}$ The habit of assessing development by means of quantitatively measuring the proliferation of mass culture was also not unique to the Eastern block. Literacy rates, newspaper circulation, cinema seats and radio receivers per capita were all indicators widely adopted in post-war American studies of modernization and development. ${ }^{70}$ Nor were these attitudes to, and uses of, mass culture limited to the post-war period. In the 1920 and the 1930s, meanings associated with the masses in both the Soviet Union and the United States were largely positive, and in both countries, mass culture, in particular cinema, played a key role in promoting official, utopian visions of the present and future. ${ }^{71}$ The same applies to the history of 'culture counting' that became widespread across Europe already in the nineteenth century, ${ }^{72}$ as modern states started perceiving themselves as responsible for the cultural education of their populations.

\section{Conclusions}

In sum, the normative distinctions permeating the journalistic writings about culture in the northwest of Yugoslavia in the post-war years served a number of distinct ends, all of which were intimately linked to the production of a sense of a Yugoslav self and its internal and external others. On the one hand, the Cold War binaries helped legitimize the authority of cultural institutions and the communist authorities at large, as well as served to establish hierarchical relationships between cultural products, events and forms produced by local institutions, groups and individuals. On the other hand, they were also instrumental in situating the here and now of Yugoslav culture vis-à-vis the then and there of its pre-war past and Western capitalism. As pointed out throughout the chapter, the normative distinctions drawn by the media provide a rather poor guide to the actual reality of cultural practices, values and products both within and beyond Yugoslavia. Above all, they downplay the similarities between perceptions of culture on both sides of the Iron Curtain, and neglect their shared roots

\footnotetext{
${ }^{68}$ Andrew Ross, 'Containing Culture in the Cold War', Cultural Studies, Vol. 1, No. 3, pp. 328-348 (1987).

${ }^{69}$ E.g. Lerner, The Passing of Traditional Society; Lucian W. Pye, The Concept of Political Development, Annals of the American Academy of Political and Social Science, Vol. 358, No. 1, pp. 113 (1965).

${ }^{70}$ E.g. Deutsch, op.cit.; Everett M Rogers, Mass Media Exposure and Modernization among Columbian Peasants, Public Opinion Quarterly, Vol. 29, pp. 614-625 (1965).

${ }^{71}$ Susan Buck-Morss, Dreamworld and Catastrophe. The Passing of Mass Utopia in the East and West (Cambridge and London: MIT Press, 2000), pp. 147-61.

${ }^{72}$ Vincent, op.cit., pp. 4-5.
} 
This is a pre-print version. Final version published in: Peter Romijn, Giles ScottSmith and Joes Segal 2012 (eds.) Divided Dreamworlds: The Cultural Cold War in East and West, Amsterdam: Amsterdam University Press.

that stem from the cultural norms, attitudes and practices established already in the nineteenth century.

Nevertheless, this mismatch between cultural dreamworlds and realities should not lead us to discount the Cold War binaries as entirely irrelevant to our understanding of the cultural history of this period. However far from reality they were, the cultural dreamworlds of the Cold War provided the ideological blueprints of institutional forms and practices, which in turn endowed them with the power to mould reality in their own image, and brush over those aspects that did not quite fit the picture. Understanding the logic of these institutionally supported dreamscapes can therefore help explain why so many people were willing to overlook the gap that separated these idealistic visions from the reality they lived in. Arguably, explaining this state of oblivion, be it willful or not, is just as vital to our understanding of Cold War history as the investigation of the various ways in which social actors may have resisted, ignored or otherwise 'made do' with or indeed eschewed the logic of Cold War rhetoric. Without that, we are running the risk of reducing our account of really existing socialisms to one that contrasts official imposition with popular resistance, repression with dissidence, and as such - though perhaps well attuned to contemporary political interests and divided memories of the period - has little to do with the actual logic and power of socialist dreams and nightmares. 